\title{
Tıp Fakültesi Öğrencilerinin Tıbbi Malpraktis Bilgi Düzeyi
}

\author{
Medical Malpractice Knowledge Level of Faculty of Medicine Students
}

Eskișehir Osmangazi Üniversitesi Tip Fakültesi Halk Sağıı̆̆ı Anabilim Dalı Eskişehir, Türkiye

\section{Correspondence:}

Sevil AYDOĞAN GEDİK - Eskișehir Osmangazi Üniversitesi Tip Fakültesi Halk Sağlığı Anabilim Dalı, Eskișehir, Türkiye e-mail: aydogan.sevil@gmail.com

\section{Sevil Aydoğan Gedik, Alaettin Ünsal, Didem Arslantaş, Ayşegül Mutlu}

$\mathrm{Bu}$ çalş̧̧ma, Tip Fakültesi öğrencilerinin tıbbi malpraktis bilgi düzeylerinin saptanması, ilişkili olduğu düşünülen bazı değişkenlerin incelenmesi ve tıbbi hatalara karşı tutumlarının değerlendirilmesi amacı ile yapılmıștır. Çalıșma, bir Tip Fakültesinde öğrenim görmekte olan öğrenciler üzerinde yapılan kesitsel tipte bir araştırmadır. Çalışma grubu 916 öğrenciden oluşmuştur. Malpraktis bilgi düzeyi literatürden faydalanılarak hazırlanan 25 bilgi sorusu ile, tıbbi hatalara karşıı tutumları ise Tibbi Hatalarda Tutum Ölçeği ile değerlendirilmiștir. Malpraktis bilgi düzeyi yeterliliğ̌i Roc analizi ile değerlendirildi. Analizler için Ki-kare testi, lojistik regresyon analizi ve Spearman korelasyon analizi kullanıldı. Öğrencilerin \%51.9’u kadın, \%48.1’i ise erkektir. Yaşları 18-40 arasında değişmekte olup, ortalama $20.91 \pm 2.11$ yıl idi. Öğrencilerden $\% 66.8$ 'inin malpraktis bilgi düzeyi yeterliydi. Parçalanmış aileye sahip olmak, 19 yaş ve altında olmak ve baba öğrenim durumunun ilkokul altında olması malpraktis bilgi düzeyi yeterliliğin azaltan faktörler olarak saptandı. Malpraktis kavramını daha önceden duyanlarda (OR: 3.54), malpraktis hakkında daha önceden bilgi alanlarda (OR: 1.75) ve hekim hak ve sorumlulukları hakkında eğitim alanlarda (OR: 1.54) malpraktis bilgi düzeyi yeterliliğinin daha yüksek olduğu bulundu. Öğrencilerin malpraktis bilgi sorularından aldıkları puanlar ile Tibbi Hatalarda Tutum Ölçeğinden aldıkları puanlar arasında pozitif yönde zayıf bir ilişki olduğu saptandı $(r=0.288, p<0.001)$. Öğrencilerin çoğunun malpraktis bilgi düzeyi yeterliydi. Malpraktis bilgi düzeyi ile tıbbi hatalarda tutum düzeyi arasında pozitif yönde zayıf bir ilişki vardır.

Anahtar Kelimeler: Malpraktis, tıbbi hata, bilgi, tutum

\section{Abstract}

The aim of this study is to determine the medical malpractice knowledge levels of the students of the Faculty of Medicine, to examine somevariables which mayberelated and to evaluate their attitudestowards medical errors. Thisis a crosssectional study conducted in a Faculty of Medicine. The study group consisted of 916 students. The knowledge level of malpractice was evaluated with 25 information questions based on the literature and the attitudes towards medical errors were evaluated by the Medical Errors Attitude Scale (MEAS). Malpractice knowledge level sufficiency was evaluated by Roc analysis. Chi-square, logistic regression and Spearman correlation analyses were used. In the study, $51.9 \%$ of the students were female, $48.1 \%$ were male and the mean of ages was $20.9 \pm 2.1$ years (ranged $18-40$ ). The $66.8 \%$ of students had sufficient knowledge of malpractice. Having a broken family, being 19 years and under and the father's education is under primary school were identified as factors reducing the level of malpractice knowledge. It was found that the malpractice knowledge level was higher in those who had previously heard malpractice (OR:3.54), who had previously learned about malpractice (OR:1.75) and who were educated about physician rights and responsibilities (OR:1.54). There was a positive weak correlation between the scores of malpractice information questions and the MEAS $(\mathrm{r}=0.288, \mathrm{p}<0.001)$. Malpractice knowledge level of most students was sufficient. There is a positive weak relationship between the malpractice knowledge level and the level of attitude in medical errors.

Keywords: malpractice, medical error, knowledge, attitude 


\section{Giriş}

Tibbi hata bir girişim, tedavi ya da uygulamanın sadece yanlış veya eksik yapılması değil, yapılması gerektiği halde yapılmaması ve yapılmaması gerektiği halde yapılmas1 olarak tanımlanmaktadır (1). Yorgunluk, eğitim eksikliği, özensizlik, dikkatsizlik ve iletişim eksikliği gibi kişisel faktörler; iş yeri yapısı, iş ve hasta yükü, çalışma saatleri, personelin sayıca eksikliği ve yanlış dağılımı gibi kurumsal faktörler; yanlış laboratuvar sonuçları, yetersiz ve eksik cihazlar gibi teknik faktörler tıbbi hatalara yol açabilir (2-4). Tıbbi hatalar sonucu sağlık personelinde moral ve motivasyon kaybi, depresyon, öfke ve hukuksal sorunlarla karş1 karşıya gelmenin yarattı̆g 1 diğer duygusal rahatsızlıklar meydana gelmektedir. Diğer yandan hastanın hastanede yatış süresi uzamakta, mortalite ve morbidite artmakta, en sonunda da toplumun sağlık düzeyinde azalma olmaktadır $(5,6)$. Ushie ve arkadaşlarının çalışmasında hastaların yarısının geçmişte bir tıbbi hataya maruz kaldığı belirtilmiştir (7).

Tıbbi hata sonucunda kişinin sağlığında herhangi bir olumsuzluk meydana gelirse, bu durum malpraktis olarak değerlendirilir (8). Hekimin tedavi sırasında standart ve güncel uygulamayı yapmaması, beceri eksikliği veya hastaya tedavi vermemesi ile oluşan zarar tıbbi malpraktis (tıbbi uygulama hatası) olarak tanımlanmaktadır $(9,10)$.

Türkiye'de hekimlerin cezai ve hukuki sorumluluğunu düzenleyen, malpraktis ile ilgili özel bir kanun yoktur. Malpraktis davalarında kararlar, Türk Ceza Kanunu'ndaki taksirle yaralama ve taksirle öldürme gibi maddelere göre verilmektedir. $\mathrm{Bu}$ da suçlayıcı-cezalandırıcı sistemi öne çıkarmaktadır. $\mathrm{Bu}$ sistem içinde maddi tazminat cezası verilebileceği gibi uyarma, kınama, kademe ilerlemesinin durdurulması ve maaş kesme gibi idari cezalar da verilebilmektedir $(9,11,12)$. Türkiye'de 2002-2014 yıllar1 arasında malpraktis iddias1 ile toplam 4470 dava açılmış olup, bunlardan 764'ünde hekimler 7.254.000 TL maddi tazminat ödemeye mahkum edilmiştir (13).
Bir çalışmada hekim ve hemşirelerin mesleki açıdan kaygı duydukları en önemli durumun malpraktis olduğu bildirilmiştir (14). Tibbi uygulamalardan dolayı hasta ve yakınları tarafindan şikayet edilme, malpraktis davası açılma endişesi hekimin çekinik davranmasına yol açmakta, dolayisıyla hastaya sunduğu sağlık hizmetini olumsuz yönde etkilemektedir. Defansif tıp olarak tanımlanan bu anlayışta, hekimlerin riskli hastaları tedavi etmekten, riskli işlemler veya yapabilecekleri girişimlerden kaçınmaları, kendilerini güvence altına almak için gereğinden fazla tetkik ve tahlil istemeleri ve düşük riskli hastaları bile hastaneye yatırmaları sağlık hizmeti harcamalarının artmasina neden olmaktadir (9, 15-17). Amerika Birleşik Devletleri'nde (ABD) ortopedistlerin \%96'sının malpraktisten korunmak için defansif tıp anlayışına göre hareket ettikleri, istedikleri tahlil ve tetkiklerin \%24'ünün defansif anlayıştan kaynaklandığı ve bu anlayıştan dolayı sadece ortopedistlere atfedilebilecek tıbbi maliyetin yıllık 2 milyar dolar olduğu bildirilmiştir (18). Yine ABD'de defansif tıp anlayışından dolayı toplam yıllık 45.6 milyar dolar ekonomik yük olduğu rapor edilmiştir (19). Defansif anlayış nedeniyle artan bu mali yük, halkın gerçekten ihtiyaç duyduğu sağlık hizmetlerine sinırlama getirmekte, halk sağlığını olumsuz etkilemektedir (20). Türkiye'de yapılan bazı çalışmalarda defansif tıp anlayışına göre hareket eden hekimlerin \%77.6-\%93.6 arasında değiştiği bildirilmiştir (21-23). Hekimlerin \%75.7'sinin malpraktis iddiasından korunmak için daha fazla tetkik istediği, \%81.7'sinin malpraktis davası açılma korkusunun hastaya sunulan hizmeti olumsuz etkileyeceğini düşündüğü rapor edilmiştir (21, 23). Ceza alma, şiddet görme ve itibar kaybı korkusu gibi nedenlerle hekimler yaptıkları tıbbi hataları bildirmekten kaçınabilirler. Tibbi hataların bildirilmemesi ise tıbbi hata nedenlerinin belirlenmesini, yapılan hatanın bir daha tekrarlanmaması için çözümler üretilip gerekli iyileştirmelerin yapılmasını engeller $(12,24)$. Tip öğrencilerinde ise defansif tıp anlayışının yansımaları, malpraktisten korunmak için riskli branşları seçmeme olarak kendini göstermektedir. 
Tipta ve sağlık hizmetlerinin sunumunda meydana gelen gelişmelerle hastaların beklentilerinin ve taleplerinin artması, medyada malpraktis davaları ve hekim hataları ile ilgili haberlerin çoğalması ve iletişim teknolojilerinin gelişmesiyle hastaların bilgiye ulaşmasının kolaylaşması, bilinçlenmeleri ve haklarını daha fazla aramaları malpraktis davalarının sayısında artışa yol açmıştır $(4,13,21,25)$.

Malpraktis, hekimlerin çoğunun karşılaşabileceği ve hukuki süreçler yaşayabileceği önemli bir durum olmasına rağmen, hekimlerin bu konudaki bilgilerinin yetersiz olduğu görülmektedir. Roy ve arkadaşları hekimlerin çoğunun malpraktis ile ilgili herhangi bir eğitim almadığını ve bilgilerinin yetersiz olduğunu belirtmiştir (6). Kumral ve arkadaşlarının yaptığı bir çalışmada mezuniyet öncesi ve sonrası malpraktisle ilgili verilen eğitimi yeterli bulan hekimlerin sadece \%11.7 olduğu, Y1ldırım ve arkadaşlarının çalışmasında da hekimlerin \%85.9'unun tıp eğitimi boyunca hekim hak ve sorumlulukları ile ilgili verilen eğitimi yetersiz bulduğu bildirilmiştir $(9,23)$. Zhao ve arkadaşları da tıp fakültesinde standart müfredat olmaması sonucu, tıp hukuku ve adli bilgiler konusunda eğitimin eksik olduğunu bildirmiştir (26). Hekimlerin malpraktisten korunmaları için malpraktis konusunda bilgili olmaları, hak ve sorumluluklarını bilmeleri önemlidir. Bunun için de tıp fakültesinde malpraktisle ilgili verilen eğitim son derece önemlidir.

$\mathrm{Bu}$ çalışma, Tıp Fakültesi öğrencilerinin tıbbi malpraktis bilgi düzeylerinin saptanması, ilişkili olduğu düşünülen bazı değişkenlerin incelenmesi ve tıbbi hatalara karşı tutumlarının değerlendirilmesi amacı ile yapılmıştır.

\section{Gereç ve Yöntem}

$\mathrm{Bu}$ çalışma, 01.02.2019-30.04.2019 tarihleri arasında bir Tip Fakültesinde öğrenim görmekte olan öğrenciler üzerinde yapılan kesitsel tipte bir araştırmadır.

Çalışmanın yapılabilmesi için Eskişehir Osmangazi Üniversitesi Girişimsel Olmayan Klinik Araştırmalar Etik Kurulunun
15.02.2019 tarih ve 25403353-050.99E.20485 sayılı onay1 ve T1p Fakültesi Dekanlığından gerekli olan izin alınmıştır.

$\mathrm{Bu}$ çalışmanın amacina uygun olarak literatürden de faydalanılarak bir anket form hazırlanmıştır (4, 11-13, 27-29). Anket form 3 bölümden oluşmakta olup, birinci bölümü öğrencilerin bazı sosyodemografik özellikleri (yaş, cinsiyet, sınıf, anne öğrenim durumu, baba öğrenim durumu, aile tipi, gelir durumu) ve malpraktis bilgi düzeyi ile ilişkili olduğu düşünülen bazı değişkenleri (malpraktis kavramını daha önce duyma durumu, malpraktis hakkında önceden bilgi alma durumu, tıp eğitimi boyunca hekim hak ve sorumlulukları hakkında bilgi alma durumu, aile ve yakın çevresinde malpraktis nedeniyle dava açılan birinin varlığı ve malpraktise yol açan önemli sebepler neler olduğu), ikinci bölümü malpraktis bilgi düzeyinin değerlendirilmesi amaciyla literatürden faydalanılarak hazırlanan 25 bilgi sorusunu, üçüncü bölümü ise Tibbi Hatalarda Tutum Ölçeğinin sorularını içermektedir.

Çalışmanın yapıldığı üniversitede 2018-2019 eğitim öğretim yılında öğrenim görmekte olan öğrenci say1s1 toplam 31.748 olup, bunlardan 1519'u (\%4.7) Tip Fakültesi öğrencisidir. Bu çalışmada Tıp Fakültesinde öğrenim görmekte olanların tamamına ulaşılması hedeflenmiştir. T1p Fakültesi öğretim üyeleri ile görüşülerek veri toplama gün ve saatleri belirlendi. Belirlenen gün ve saatlerde öğrencilerin sinıflarında ve staj yapmakta oldukları bölümlerde toplanmaları sağlandı. Öğrenciler çalışmanın konusu ve amacı hakkında bilgilendirildikten sonra, çalışmaya katılmayı kabul edenlerden sözlü onamları alındı. Önceden hazırlanmış olan anket formlar gözlem altında öğrencilerin kendileri tarafından dolduruldu. Bu işlem yaklașık 1015 dakika sürdü. Çalışma süresince okulda bulunan ve çalışmaya katılmayı kabul eden toplam 916 öğrenci (\%60.3) çalışma grubunu oluşturdu.

Çalışmamızda öğrencilerin malpraktis ile ilgili bilgi düzeyleri, literatürden faydalanılarak hazırlanan 17'si doğru, 8'i yanlış olmak üzere toplam 25 bilgi sorusu ile değerlendirildi (4, 11, 12, 28, 29). Malpraktis bilgi düzeyi için 
oluşturulan 25 bilgi sorusu için Cronbach's Alpha 0.926 olarak hesaplandi. Bilgi sorularına verilen her bir doğru cevap "1 puan" olarak değerlendirildi. Öğrencilerin bilgi sorularından alabilecekleri puanlar 0-25 arasında değişmekte olup, puan arttıkça malpraktis bilgi düzeyi de artmaktadır. Bilgi sorularından alınan puanlar K-Means kümeleme analizi ile 2 kümeye ayrıldı. Daha sonra bu küme özellikleri referans alınarak elde edilen puanlar Roc Analizi ile değerlendirildi (30). Roc Analizi sonucunda 8.5 ve üzeri puan alanlar malpraktis bilgi düzeyi yeterli olarak kabul edildi.

Öğrencilerin tıbbi hatalara karşı tutumları, Tibbi Hatalarda Tutum Ölçeği ile değerlendirilmiştir. Bu ölçek, 2012 yılında Güleç tarafından geliştirilmiş olup, 5'li Likert tipi 16 sorudan oluşmaktadır. Sorulara verilebilecek cevaplar 'tamamen katıliyorum' 5 puan, 'katılıyorum' 4 puan, 'kararsızım' 3 puan, 'katılmıyorum' 2 puan, 'hiç katılmıyorum' 1 puan şeklinde değerlendirilir. Ölçekte yer alan 10 ve 13. sorular ters puanlanır. Ölçek toplam puanı 16 sorudan alınan puanların toplanarak soru sayısına bölünmesi ile elde edilir. Ölçekten alınabilecek toplam puan 1-5 arasında değişmekte olup, alınan puanlar arttıkça olumlu tutum düzeyi de artar. Yani tıbbi hata ve hata bildiriminin önemi hakkındaki farkındalığın $\quad \operatorname{arttığı}$ şeklinde yorumlanmaktadır (27).

Elde edilen verilerin analizi SPSS (versiyon 15.0) İstatistik Paket Programında değerlendirilmiştir. Ölçülebilir verilerin normal dağılıma uygunluğu Shapiro-Wilk testi ile yapılmıştır. İstatistiksel analizler için Ki-kare testi, Lojistik Regresyon analizi (Backward: Wald) ve Spearman Korelasyon analizi kullanılmıştır. İstatistiksel anlamlılık değeri olarak $p \leq 0.05$ kabul edilmiştir.

\section{Bulgular ve Analizler}

Çalışma grubunu oluşturanların 475'i (\%51.9) kadın, 441'i (\%48.1) ise erkektir. Yaşları 1840 arasında değişmekte olup, ortalama $20.91 \pm 2.11$ y1l idi. Öğrenciler arasında malpraktis bilgi düzeyi yeterli olanların sayısı 612 (\%66.8)'dir. Çalışma grubunda malpraktis bilgi düzeyi yeterli olan ve olmayanların bazı sosyodemografik özelliklere göre dağılımı Tablo 1'de verilmiştir.

Tablo 1. Çalışma grubunda malpraktis bilgi düzeyi yeterli olan ve olmayanların bazı sosyodemografik özelliklere göre dağılımı

\begin{tabular}{|c|c|c|c|c|}
\hline \multirow[t]{2}{*}{ Bazı sosyodemografik özellikler } & \multicolumn{3}{|c|}{ Malpraktis bilgi düzeyi } & \multirow{2}{*}{$\begin{array}{c}\text { İstatistiksel } \\
\text { değer } \\
\chi^{2} ; \mathbf{p}\end{array}$} \\
\hline & $\begin{array}{l}\text { Yetersiz } \\
\mathrm{n}(\%)^{*}\end{array}$ & $\begin{array}{l}\text { Yeterli } \\
\mathrm{n}(\%)^{*}\end{array}$ & $\begin{array}{l}\text { Toplam } \\
\mathrm{n}(\%)^{* *}\end{array}$ & \\
\hline \multicolumn{5}{|l|}{ Yaş grubu } \\
\hline$\leq 19$ & $136(53.8)$ & $117(46.2)$ & $253(27.6)$ & \multirow[t]{3}{*}{$71.892 ; 0.000$} \\
\hline $20-21$ & $102(29.3)$ & $246(70.7)$ & $348(38.0)$ & \\
\hline$\geq 22$ & $66(21.0)$ & $249(79.0)$ & $315(34.4)$ & \\
\hline \multicolumn{5}{|l|}{ Cinsiyet } \\
\hline Kadın & $154(32.4)$ & $321(67.6)$ & $475(51.9)$ & \multirow[t]{2}{*}{$0.262 ; 0.609$} \\
\hline Erkek & $150(34.0)$ & $291(66.0)$ & $441(48.1)$ & \\
\hline \multicolumn{5}{|l|}{ Sinıfi } \\
\hline$\leq 3$ & $248(40.8)$ & $360(59.2)$ & $608(66.4)$ & \multirow[t]{2}{*}{$47.123 ; 0.000$} \\
\hline$\geq 4$ & $56(18.2)$ & $252(81.8)$ & $308(33.6)$ & \\
\hline \multicolumn{5}{|l|}{ Aile gelir durumu } \\
\hline Kötü & $13(48.1)$ & $14(51.9)$ & $27(2.9)$ & \multirow{3}{*}{$6.877 ; 0.032$} \\
\hline Orta & $248(34.3)$ & $476(65.7)$ & $724(79.0)$ & \\
\hline İyi & $43(26.1)$ & $122(73.9)$ & $165(18.0)$ & \\
\hline \multicolumn{5}{|l|}{ Aile tipi } \\
\hline Çekirdek aile & $256(31.9)$ & $547(68.1)$ & $803(87.7)$ & \multirow[t]{2}{*}{$11.950 ; 0.003$} \\
\hline Geniş aile & $35(37.2)$ & $59(62.8)$ & $94(10.3)$ & \\
\hline
\end{tabular}




\begin{tabular}{lcccc}
\hline Parçalanmış aile & $13(68.4)$ & $6(31.6)$ & $19(2.1)$ & \\
Anne öğrenim düizeyi & & & & \\
Okulsuz & $22(47.8)$ & $24(52.2)$ & $46(5.0)$ & $4.681 ; 0.096$ \\
İllkokul ve ortaokul & $91(32.4)$ & $190(67.6)$ & $281(30.7)$ & \\
Lise ve üzeri & $191(32.4)$ & $398(67.6)$ & $589(64.3)$ & \\
Baba öğrenim düizeyi & & & & \\
Okulsuz & $11(61.1)$ & $7(38.9)$ & $18(2.0)$ & $\mathbf{6 . 6 7 0 ; 0 . 0 3 6}$ \\
IIllkokul ve ortaokul & $63(34.1)$ & $122(65.9)$ & $185(20.2)$ & \\
Lise ve üzeri & $230(32.3)$ & $483(67.7)$ & $713(77.8)$ & \\
Toplam & $304(33.2)$ & $612(66.8)$ & $916(100.0)$ & \\
\hline *Satr toplamina göre **Sütun toplamina göre yüzde alnmıştr. & &
\end{tabular}

Çalışma grubunu oluşturanların \%17.8'i $(\mathrm{n}=163)$ tıp fakültesini seçmekten dolayı memnun olmadığını bildirdi. Daha önce malpraktis kavramını duyanların sayıs 607 (\%66.3), malpraktis hakkında bilgi alanların

sayısı ise 489 (\%53.4) idi. Çalışma grubunda malpraktis bilgi düzeyi yeterli olan ve olmayanların malpraktis bilgi düzeyi ile ilişkili olduğu düşünülen bazı değişkenlere göre dağılımı Tablo 2'de verilmiştir.

Tablo 2. Çalışma grubunda malpraktis bilgi düzeyi yeterli olan ve olmayanların malpraktis bilgi düzeyi ile ilişkili olduğu düşünülen bazı değişkenlere göre dağılımı

\begin{tabular}{|c|c|c|c|c|}
\hline \multirow{2}{*}{$\begin{array}{l}\text { Malpraktis bilgi düzeyi ile illişkilii } \\
\text { bazı değişkenler }\end{array}$} & \multicolumn{3}{|c|}{ Malpraktis bilgi düizeyi } & \multirow{2}{*}{$\begin{array}{c}\text { İstatistiksel } \\
\text { değer } \\
\chi^{2} ; \mathrm{p}\end{array}$} \\
\hline & $\begin{array}{l}\text { Yetersiz } \\
\mathrm{n}(\%)^{*}\end{array}$ & $\begin{array}{l}\text { Yeterli } \\
\mathrm{n}(\%)^{*}\end{array}$ & $\begin{array}{l}\text { Toplam } \\
\mathrm{n}(\%)^{* *}\end{array}$ & \\
\hline \multicolumn{5}{|l|}{$\begin{array}{l}\text { Tıp Fakültesini seçmekten dolayı } \\
\text { memnuniyet durumu }\end{array}$} \\
\hline Memnun değil & $66(40.5)$ & $97(59.5)$ & $163(17.8)$ & \multirow{3}{*}{$4.769 ; 0.029$} \\
\hline Memnun & $238(31.6)$ & $515(68.4)$ & $753(82.2)$ & \\
\hline \multicolumn{4}{|l|}{$\begin{array}{l}\text { Malpraktis kavramını daha } \\
\text { önceden duyma durumu }\end{array}$} & \\
\hline Duymamış & $188(60.8)$ & $121(39.2)$ & $309(33.7)$ & \multirow{3}{*}{$160.819 ; 0.000$} \\
\hline Duymuş & $116(19.1)$ & $491(80.9)$ & $607(66.3)$ & \\
\hline \multicolumn{4}{|l|}{$\begin{array}{l}\text { Malpraktis hakkında daha önceden } \\
\text { bilgi alma durumu }\end{array}$} & \\
\hline Almamış & $220(51.5)$ & $207(48.5)$ & $427(46.6)$ & \multirow{3}{*}{$121.260 ; 0.000$} \\
\hline Almış & $84(17.2)$ & $405(82.8)$ & $489(53.4)$ & \\
\hline \multicolumn{4}{|l|}{$\begin{array}{l}\text { Tıp eğitimi boyunca hekim hak ve } \\
\text { sorumlulukları hakkında eğitim } \\
\text { alma durumu }\end{array}$} & \\
\hline Almamış & $183(39.8)$ & $277(60.2)$ & $460(50.2)$ & \multirow{3}{*}{$18.124 ; 0.000$} \\
\hline Almış & $121(26.5)$ & $335(73.5)$ & $456(49.8)$ & \\
\hline $\begin{array}{l}\text { Ailesi / yakın çevresinde malpraktis } \\
\text { davası açılan birinin varlığı }\end{array}$ & & & & \\
\hline Yok & $289(34.0)$ & $561(66.0)$ & $850(92.8)$ & \multirow[t]{3}{*}{$3.510 ; 0.061$} \\
\hline Var & $15(22.7)$ & $51(77.3)$ & $66(7.2)$ & \\
\hline Toplam & $304(33.2)$ & $612(66.8)$ & $916(100.0)$ & \\
\hline
\end{tabular}

*Satır toplamına göre **Sütun toplamına göre yüzde alınmıştır.

Çalışmamızda malpraktis bilgi düzeyi ile ilişskili olduğu saptanan yaş, sınıf, aile gelir durumu, aile tipi, baba ögrenim durumu, tıp fakültesini seçmekten dolayı memnuniyet durumu, malpraktis kavramını daha önceden duyma durumu, malpraktis hakkında daha önceden bilgi alma durumu, tıp eğitimi boyunca hekim hak ve sorumlulukları hakkında eğitim alma durumu ve ailesi/yakın çevresinde malpraktis davası açılan birinin varlığ gibi değişkenlerle oluşturulan Lojistik 
Regresyon Analizi sonuçları Tablo 3'te verilmiştir.

Tablo 3. Çalışma grubunda malpraktis bilgi düzeyi ile işkili olduğu saptanan değişkenlerle oluşturulan Lojistik Regresyon Modeli sonuçları (final step)

\begin{tabular}{|c|c|c|c|c|c|}
\hline \multirow{2}{*}{\multicolumn{6}{|c|}{\begin{tabular}{l}
\multicolumn{1}{c}{ Değişkenler } \\
Yaş grubu \\
(referans: $\leq 19$ )
\end{tabular}}} \\
\hline & & & & & \\
\hline 20-21 & 0.586 & 0.192 & 0.002 & 1.796 & $1.233-2.616$ \\
\hline$\geq 22$ & 0.841 & 0.217 & 0.000 & 2.319 & $1.516-3.547$ \\
\hline \multicolumn{6}{|l|}{$\begin{array}{l}\text { Aile tipi } \\
\text { (referans: parçalanmış aile) }\end{array}$} \\
\hline Geniş aile & 1.488 & 0.613 & 0.015 & 4.426 & 1.332-14.707 \\
\hline Çekirdek aile & 1.711 & 0.565 & 0.002 & 5.535 & $1.828-16.759$ \\
\hline \multicolumn{6}{|l|}{$\begin{array}{l}\text { Baba öğrenim durumu } \\
\text { (referans: Okulsuz) }\end{array}$} \\
\hline İlkokul-ortaokul & 1.399 & 0.576 & 0.015 & 4.051 & $1.309-12.538$ \\
\hline Lise ve üzeri & 1.396 & 0.561 & 0.013 & 4.040 & $1.346-12.129$ \\
\hline \multicolumn{6}{|l|}{$\begin{array}{l}\text { Malpraktis kavramını daha } \\
\text { önceden duyma durumu } \\
\text { (referans: duymamış) }\end{array}$} \\
\hline Duymuş & 1.264 & 0.217 & 0.000 & 3.541 & 2.315-5.415 \\
\hline \multicolumn{6}{|l|}{$\begin{array}{l}\text { Malpraktis hakkında daha } \\
\text { önceden bilgi alma durumu } \\
\text { (referans: almamış) }\end{array}$} \\
\hline Almış & 0.562 & 0.219 & 0.010 & 1.753 & 1.141-2.695 \\
\hline \multicolumn{6}{|l|}{$\begin{array}{l}\text { Hekim hak ve sorumlulukları } \\
\text { hakkında eğitim alma durumu } \\
\text { (referans: almamış) }\end{array}$} \\
\hline Almış & 0.434 & 0.162 & 0.007 & 1.543 & $1.123-2.120$ \\
\hline Sabit & -4.033 & 0.815 & 0.000 & - & - \\
\hline
\end{tabular}

Çalışma grubundakiler malpraktis bilgi sorularından aldıkları puanlar 0-23 arasında değişmekte olup, ortalama $9.95 \pm 5.58$ (ortanca 11.0) idi. Tibbi Hatalarda Tutum Ölçeğinden aldıkları puanlar ise $1.50-4.75$ arasinda değişmekte olup, ortalama $3.51 \pm 0.43$ (ortanca 3.56) idi. Çalışma grubundakilerin malpraktis bilgi sorularından aldıkları puanlar ile Tıbbi Hatalarda Tutum Ölçeğinden aldıkları puanlar arasında pozitif yönde zayıf bir ilişki olduğu saptand $1(\mathrm{r}=0.288, \mathrm{p}<0.001)$. Malpraktis bilgi sorularından alınan puanlar ile Tibbi Hatalarda Tutum Ölçeği'nden alınan puanların dağılımı Şekil 1'de gösterilmiştir.

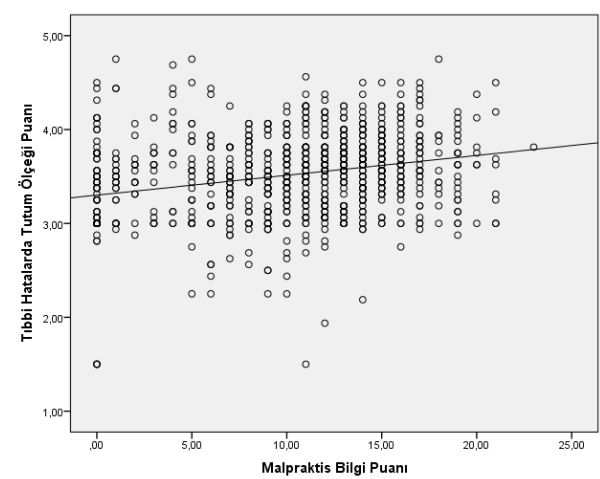

Şekil 1. Malpraktis bilgi sorularından alınan puanlar ile Tıbbi Hatalarda Tutum Ölçeği'nden alınan puanların dağglımı 
Öğrencilerden 489’u (\%53.4) daha önceden malpraktis hakkında bilgi aldığını bildirdi. Malpraktis hakkında bilgi edinilen kaynaklar arasında en çok \%40.2 ile tıp eğitimi, en az ise
\%5.6 ile bilimsel yayınların yer aldığ 1 saptanmıştır. Öğrencilerin malpraktis hakkında bilgi edindikleri kaynakların dağılımı Tablo 4'te verilmiştir.

Tablo 4. Öğrencilerin malpraktis hakkında bilgi edindikleri kaynaklar

\begin{tabular}{lcc}
\hline Bilgi Kaynă̆ı & $\mathbf{n}^{*}$ & $\mathbf{\%}$ \\
\hline Tıp Eğitimi & 227 & 40.2 \\
\hline Tv / Gazete / İnternet & 119 & 21.1 \\
\hline Kongre, Sempozyum ve Diğer Bilimsel Etkinlikler & 109 & 19.3 \\
\hline Hekimler & 78 & 13.8 \\
\hline Bilimsel Yayınlar & 32 & 5.6 \\
\hline Toplam & 565 & 100.0 \\
\hline
\end{tabular}

*Sayılar bilgi edinilen kaynaklar üzerinden hesaplanmıştır.

Öğrenciler malpraktise yol açan önemli sebepler içinde en çok hekimin kişisel kusurları (\%11.2) ve aşırı hasta yükü (\%11.2), en az ise yönetimsel sorunlar
(\%5.3) olduğunu bildirmişlerdir. Öğrencilere göre malpraktise yol açan önemli durumların dağılımı Tablo 5'te verilmiştir.

Tablo 5. Öğrencilere göre malpraktise yol açan önemli durumlar

\begin{tabular}{|c|c|c|}
\hline Malpraktise yol açan durumlar & $n *$ & $\%$ \\
\hline Hekimin kişisel kusurları (bilgi, deneyim, dikkat eksikliği) & 637 & 11.2 \\
\hline Aşırı hasta yükü & 637 & 11.2 \\
\hline Uzun çalıșma saatleri & 609 & 10.7 \\
\hline Sağlık personelinin olumsuz çalıșma koşulları & 535 & 9.4 \\
\hline İletişim sorunları & 493 & 8.6 \\
\hline Gerekli sayıda ne nitelikte ekip üyesinin bulunmaması & 492 & 8.6 \\
\hline Ekipman, araç-gereç ve mekan yetersizliği & 465 & 8.1 \\
\hline Sağlık finansmanındaki yetersizlik & 410 & 7.2 \\
\hline Fiziksel ortamın olumsuz olması (ıSı, ışık, gürültü) & 397 & 7.0 \\
\hline Diğer sağlık personelinin hatalı uygulamalar yapması & 380 & 6.6 \\
\hline Hastanın konsültasyonundaki sorunlar & 349 & 6.1 \\
\hline Yönetimsel sorunlar & 303 & 5.3 \\
\hline Toplam & 5707 & 100.0 \\
\hline
\end{tabular}

*Sayılar malpraktise yol açan durumlar üzerinden hesaplanmıştır

\section{Tartışma ve Sonuç}

Günümüzde giderek artan malpraktis davaları, tıp fakültesi öğrencilerinin ileride meslek hayatlarında sıkça karşılaşabilecekleri bir sorun haline gelmiştir. Öğrencilerin malpraktis hakkında bilgi düzeyleri çeşitli faktörlerce belirlenmektedir.

Çalışmamızda öğrencilerin \%66.8'inin malpraktis bilgi düzeyinin yeterli olduğu bulundu. Topal tarafindan yapılan çalışmada sağlık programı stajyer öğrencilerinin \%46.6'sinın malpraktisle ilgili bilgi sahibi olmadığı rapor edilmiştir (31). Cerrahlar ve hemşirelerde yapılan bazı çalışmalarda da malpraktis bilgisinin yetersiz olduğu görülmektedir $(24,32)$. Türkiye'de hekimlerin $\% 57.7-\% 82.0$ 'sinin malpraktisle ilgili yasal düzenlemeler hakkında yeterli bilgiye sahip olmadığı bildirilmiştir $(9,10,22,23)$. Aygün ve arkadaşları acil servislerde çalışan hekimlerin \%42'sinin hukuki sorumlulukları ile ilgili bilgi düzeylerini yetersiz olarak tanımladığını raporlamıştır (22). Zhao ve arkadaşları cerrahi asistanlarının \%68.7'sinin 
tıp hukuku ve adli bilgilerini yetersiz olarak değerlendirdiğini bildirmiștir (26). Çalışmalar farklı gruplarda yapıldığı, standart bir ölçüm aracıyla yapılmadığı ve bazı sonuçlar kişilerin kendi bildirimlerine dayandığ 1 yani sübjektif olduğu için çalışmamızda bulunan yeterli bilgi düzeyi literatürdekinden daha yüksek bulunmuş olabilir.

Yaş arttıkça öğrencilerin genel tıp bilgilerinin artmas1, hekimlik mesleği, görev ve sorumlulukları hakkında farkındalıklarının artmas1, beraberinde malpraktis bilgilerinin de artması beklenir. Çalışmamızda da yaş arttıkça malpraktis bilgi düzeyi yeterliliğinin arttığı saptanmıștır. Arıkan ve arkadaşlarının yaptığ1 çalışmada da benzer sonuç rapor edilmiştir (28). Çeşitli ülkelerde yapılan bazı çalışmalarda ise yaş ile tıbbi uygulama hataları ve yasal bilgi düzeyleri arasında fark bulunamadığı bildirilmiştir $(9,32,33)$.

Çalışmada erkekler ve kadınlar arasında malpraktis bilgi düzeyi yeterliliği açısından fark bulunamadi. Farklı sağlık meslek mensupları arasında yapılan bazı çalışmalarda da benzer sonuçlar rapor edilmiştir $(9,32)$. Tip fakültelerinin hem kadın hem erkeklerce benzer oranlarda tercih edilmesi, tıp ögrencilerinin eğitim müfredatları ve staj programlarının, karşılaşabilecekleri vakalar ve hataların cinsiyete göre değişiklik göstermeyecek durumlar olmasindan dolay1 çalışmada cinsiyete göre fark bulunamamış olabilir.

Sağllk hizmetleri sunulan yerlerde aktif olarak çalışmaya başlamak ve deneyim kazanmak tıbbi hatalar konusunda bilinci arttırarak yapılan hataları azaltmaktadır $(1,34)$. Arıkan ve arkadaşları mesleğe yeni başlayan hekimlerin malpraktis bilgi düzeylerinin, daha uzun yıllar çalışmış hekimlere göre düşük olduğunu bildirmiştir (28). Tip fakültelerinde klinik stajlara başlayan ve pratik eğitim alan, hastalara tıbbi uygulamalarda bulunan 4 . sinif ve üzerindeki öğrencilerin malpraktis bilgi düzeyinin daha yüksek olması olasıdır. Çalışmamızda da 4. sınıf ve üzerindeki öğrencilerin malpraktis hakkındaki bilgi düzeylerinin daha yeterli olduğu saptandı. Yapılan lojistik regresyon analizi sonucuna göre ise öğrenim görülen sınıfın malpraktis bilgi düzeyini etkileyen önemli bir faktör olmadığ 1 görüldü. Annandale ve ark. tarafından yapılan bir çalışmada tıp fakültesi 5. sınıf öğrencilerinin malpraktis farkındalıklarının 1. sınıfa göre daha yüksek bulunduğu bildirilmiştir (25). Yıldırım ve arkadaşlarının hukuk fakültesi öğrencilerinde yaptıkları bir çalışmada ise eğitim görülen siniflar arasında malpraktis bilgi düzeyi açısından bir fark bulunamadığı rapor edilmiştir (35).

Çalışmamızda aile tipinin malpraktis bilgi düzeyini etkileyen bir faktör olduğu, çekirdek tipi aile yapısına sahip olanlarda malpraktis bilgi düzeyi yeterliliğinin daha yüksek olduğu saptandı. Çekirdek aile içinde çocuğa daha fazla ilgi gösterilmesi ve daha çok zaman ayırılması çocuğun psikolojisini olumlu yönde etkileyerek, daha başarılı bir eğitim hayatı sürdürmesine ve okula daha az devamsizlık yapmasına olanak sağlar. Bu öğrencilerin tıpla ilgili genel bilgi düzeylerinin yanında malpraktis bilgilerinin de yüksek olması olasidir.

Çalışmada anne öğrenim durumu ile malpraktis bilgi düzeyi yeterliliği arasında bir ilişki bulunamadi. Oysa baba öğrenim düzeyi arttıkça öğrencilerin malpraktis bilgi düzeyi de artmaktaydı. Öğrenim düzeyi yüksek olan ebeveynlerin çocukları daha bilinçli bir ortamda yetişmekte, eğitim ve öğretimlerine daha çok önem verilmektedir. Bu durum da, bu öğrencilerin diğer arkadaşlarına göre meslekleri hakkında daha bilinçli ve farkındalıklarının yüksek olmasına, meslekleri ile ilgili güncel konuları ve olayları takip etmelerine, daha çok araştırmalarına sebebiyet vermektedir. Çalışmamızda baba öğrenim düzeyi arttıkça öğrencilerin malpraktis bilgi düzeylerinin artmasının sebepleri arasında, aile içinde çocuk eğitiminde babanın daha baskın olması ve rol model olarak görülmesi sayılabilir.

Tibbi hatalar ve malpraktis ile ilgili önceden alınan eğitimlerin malpraktis bilgi düzeyini yükseltmesi beklenen bir durumdur (36). Çalışmamızda da malpraktis kavramını önceden duymuş olanlarda, malpraktis hakkında önceden bilgi alanlarda ve tıp eğitimi boyunca hekim hak ve sorumlulukları 
hakkında eğitim almış olanlarda malpraktis bilgi düzeyi yeterliliğinin daha yüksek olduğu saptanmıştır (her biri için $\mathrm{p}<0.05$ ). Yapılan çeşitli çalışmalarda da malpraktis hakkında mezuniyet öncesinde veya sonrasında eğitim alan hekimlerin, malpraktis hakkında daha çok bilgiye sahip olduğu bildirilmiştir $(6,22$, 23).

Hekimlerin malpraktis konusunda doğru bilgiler edinmesi, malpraktis davalarından korunmaları, şikayet edilmeleri durumunda izleyecekleri yolu, hak ve sorumluluklarını bilmeleri için, konuyla ilgili bilgi edindikleri kaynaklar güvenilir olmalıdır. Çalışmamızda öğrencilerin malpraktis hakkında bilgi edindikleri kaynaklar en çok tıp eğitimi, medya ve kongre gibi bilimsel etkinlikler olarak saptandı. Yıldırım ve arkadaşlarının çalışmasında en çok söylenen yanıtlar bilimsel etkinlikler ve hekimler iken, tıp eğitimi son sıralarda yer almıştır (9). Annandale ve arkadaşları öğrencilerin malpraktis hakkında bilgi edinme kaynağı olarak ilk sırada medyanın, son sirada tıbbi dergilerin yer aldığını bildirmiştir (25). Texas'ta yapılmış bir çalışmada ise doktorların malpraktisle ilgili bilgilerini kişisel deneyimler ve ağızdan ağıza yayılan söylentilerden edindikleri rapor edilmiştir (37).

Çalışma grubunda aile veya yakın çevresinde malpraktis davası açılan birinin olup olmaması durumları arasında, malpraktis bilgi düzeyi yeterliliği açısından fark bulunamadı. Yıldırım ve arkadaşları tarafından yapılan bir çalışmada da soruşturma geçiren hekimlerle geçirmeyenler arasında tıbbi uygulama hataları ile ilgili bilgi düzeylerinin farklılık göstermediği rapor edilmiştir (9). Odabaşı ve ark. hekimlerin \%15.6'sının meslek uygulamalarından dolayı bir soruşturma geçirdiğini, \%72.5'inin ise Türk Ceza Kanunu'ndaki cezai sorumlulukları ile ilgili maddeleri bilmediğini bildirmiştir (38). Çevresinde malpraktis davası açılmış biri bulunan öğrencilerde, bu olayı duydukları ve farkındalıkları arttı̆gı için malpraktis bilgi düzeyinin daha yüksek olması beklenir. Çalışmamızda beklenen farkın bulunamamasının sebepleri arasında, çevresinde malpraktis davası açılan öğrenci sayısının az olması ve bilgi düzeyini etkileyen daha önemli faktörler bulunması sayılabilir.

Malpraktisle ilgili bilgi düzeyi yüksek olan ögrencilerin tıbbi hatalara yönelik tutumlarının olumlu olması beklenen bir durumdur. Tutum bireyin çevresindeki bir olgu veya nesneye karşı sergilediği davranış biçimi olup, kişinin bilgi, deneyim, inanç ve düşüncelerine bağlı olarak şekillenir (27). Çalışmamızda beklenen durumla uyumlu olarak malpraktis bilgi sorularından alınan puanlar ile Tıbbi Hatalarda Tutum Ölçeğinden alınan puanlar arasında pozitif yönde zayıf bir ilişki olduğu saptandı. Yani malpraktis bilgi düzeyi arttıkça tıbbi hatalara karşı tutumların olumlu yöne kaydığı, tıbbi hataların ve hata bildiriminin önemi konusunda farkındalığın arttığı söylenebilir. Kılıç ve arkadaşları, tıbbi hataların farkında olunduğunu fakat hata bildirimi ile ilgili eğitime ihtiyacın olduğunu rapor etmiştir (39). Bodur ve arkadaşları ebelik ve hemşirelik öğrencilerinde yaptıkları bir çalışmada, hasta güvenliğinin öneminin farkında olunduğunu, tıbbi hata yapma yüzdesinin yüksek fakat hata bildiriminin düşük olduğunu bildirmiştir (40). Skeikh ve arkadaşlarının yaptıkları çalışmada cerrahların çoğunun malpraktis tanımını bilmediği, malpraktisle ilgili farkındalıklarının düşük olduğu, fakat malpraktis yaptıklarında bunu hastaya açıklayacakları rapor edilmiştir (24).

Sonuç olarak çalışmamızda öğrencilerin üçte birinin malpraktis bilgi düzeyinin yetersiz olduğu olduğu tespit edildi. Daha genç yaşta olanlarda, parçalanmış ve geniş aile yapısına sahip olanlarda, baba öğrenim durumu düşük olanlarda, malpraktis kavramını daha önceden duymamış olanlarda, malpraktis hakkında daha önceden bilgi almamış olanlarda, hekim hak ve sorumlulukları ile ilgili eğitim almamış olanlarda malpraktis bilgi düzeyinin daha yetersiz olduğu bulundu. Malpraktis bilgi düzeyi düştükçe, tıbbi hatalara karş1 tutumların da olumsuz yönde değiştiği görüldü.

Malpraktis bilgi düzeyinin daha da arttırılması için tıp fakültesi eğitim müfredatlarına konuyla ilgili dersler eklenmeli, malpraktisle ilgili konular daha yoğun bir şekilde işlenmeli, öğrenciler hekim hak ve 
sorumlulukları, tıbbi hatalar, hata bildirim sistemleri ve hasta güvenliği hakkında daha çok eğitim almalıdır. Kongre, sempozyum gibi bilimsel etkinliklerde ve internet üzerinde tıbbi forumlarda malpraktis konusu daha sik ele alınmalı ve tartışılmalıdır. Literatürde malpraktisle ilgili tıp fakültesi öğrencilerinde yapılmış benzer çalışmalara çok az rastlanmıştır. $\mathrm{Bu}$ konuda daha kapsamlı çalışmaların yapılması yararlı olabilir.

\section{KAYNAKLAR}

1. Dikmen YD, Yorgun S, Yeşilçam N. Hemşirelerin tıbbi hatalara eğilimlerinin belirlenmesi. Hacettepe Üniversitesi Hemşirelik Fakültesi Dergisi. 2014;1:44-56.

2. Caymaz M. Sağlık personelinin tıbbi uygulama hataları üzerine bir araştırma. Uluslararası Yönetim ve Sosyal Araștırmalar Dergisi. 2015;2:114.

3. Huntington B, Kuhn N. Communication gaffes: a root cause of malpractice claims. BUMC Proceedings. 2003;16:157-61.

4. Ersoy LV. T1bbi malpraktis. Bulletin of Thoracic Surgery/Toraks Cerrahisi Bülteni. 2014;5:29-32.

5. Işık $\mathrm{O}$, Akbolat $\mathrm{M}$, Çetin $\mathrm{M}$, Çimen $\mathrm{M}$. Hemşirelerin bakış açısıyla tıbbi hataların değerlendirilmesi. TAF Prev Med Bull. 2012;11:421-30.

6. Roy AD, Chen L, Santucci K. What do pediatric residents know about malpractice? Pediatric Emergency Care. 2011;27:586-90.

7. Ushie BA, Salami KK, Jegede AS, Oyetunde M. Patients' knowledge and perceived reactions to medical errors in a tertiary health facility in Nigeria. African Health Sciences. 2013;13:820-8.

8. Çakmak C, Konca M, Teleş M. Türkiye ulusal güvenlik raporlama sistemi (GRS) üzerinden tıbbi hataların değerlendirilmesi. Hacettepe Să̆llk Ídaresi Dergisi. 2018;21:423-48.

9. Yıldırım A, Aksu M, Çetin İ, Şahan AG. Tokat ili merkezinde çalışan hekimlerin tıbbi uygulama hataları ile ilgili bilgi, tutum ve davranışları. Cumhuriyet Med J. 2009;31:356-66.

10. Teke HY, Alkan HA, Başbulut AZ, Cantürk G. Tıbbi uygulama hataları ile ilgili kanuni düzenlemelere hekimlerin bakışı ve bilgilenme düzeyi: anket çalışması. Turkiye Klinikleri J Foren Med. 2007;4:61-7.

11. Koç S. Yasal düzenlemeler çerçevesinde hekim sorumluluğu. Türkderm. 2007;41:33-8.

12. Altun G, Yorulmaz AC. Yasal değişiklikler sonrası hekim sorumluluğu ve malpraktis. Trakya Univ Tip Fak Derg. 2010;27:7-12.

13. Yıldırım İ. Tıbbi malpraktis ve hekim mesleki sorumluluk sigortası. ACU Sağlık Bil Derg. 2015;6:121-9.

14. Tülin T, Kutanis RÖ. Doktor ve hemşirelerde kayg1 nedenleri: bir üniversite hastanesi örneği. Süleyman Demirel Üniversitesi Vizyoner Dergisi. 2015;6:62-71.

15. Sungur C. Tibbi görüntüleme hizmetlerinin gereksiz kullanımı ve buna karşı öneriler. Kahramanmaraş Sütçü İmam Üniversitesi İktisadi ve İdari Bilimler Fakültesi Dergisi. 2018;8:67-86.

16. Thomas JW, Ziller EC, Thayer DA. Low costs of defensive medicine, small savings from tort reform. Health Affairs. 2010;29:1578-84.

17. Katz DA, Williams GC, Brown RL, et al. Emergency physicians' fear of malpractice in evaluating patients with possible acute cardiac ischemia. Annals of Emergency Medicine. 2005;46:525-33.

18. Sethi MK, Obremskey WT, Natividad H, Mir HR, Jahangir AA. Incidence and costs of defensive medicine among orthopedic surgeons in the United States: a national survey study. The American Journal of Orthopedics. 2012;41:69-73.

19. Mello MM, Chandra A, Gawande AA, Studdert DM. National costs of the medical liability system. Health Affairs. 2010;29:1569-77.

20. Badri M. Medical malpractice litigation: a fellow's perspective. Journal of the American College of Cardiology. 2014;64:418-9.

21. Özata M, Kubilay Ö, Akkoca Y. Konya il merkezinde çalışan hekimlerde defansif (çekinik) tıp uygulamalarının araştırılması. GÜSBD. 2018;7:132-9.

22. Aygün A, Karabacak V, Işı1k HS. Acil servis hekimlerinin tıbbi hukuki sorumlulukları hakkında bilgi, tutum ve davranışlar. KÜ Tlp Fak Derg. 2018;20:321-8.

23. Kumral B, Özdeş T. Tekirdağ ilindeki hekimlerin tıbbi uygulama hatalarına (malpraktis) bakışı ve değerlendirmeler. Int $J$ Basic Clin Med. 2013;1:83-93.

24. Sheikh A, Ali S, Ejaz S, et al. Malpractice awareness among surgeons at a teaching hospital in Pakistan. Patient Safety in Surgery. 2012;6:26.

25. Annandale E, Cunningham-Burley S. Medical students' perceptions of medical malpractice. Medical Education. 1996;30:253-8.

26. Zhao B, Cajas-Monson LC, Ramamoorthy S. Malpractice allegations: A reality check for resident physicians. The American Journal of Surgery. 2019;217:350-5.

27. Güleç D. Tıbbi hatalarda tutum ölçeğinin geliştirilmesi (Yüksek Lisans Tezi). Dokuz Eylül Üniversitesi Sağlık Bilimleri Enstitüsü, (2012). İzmir.

28. Arikan A, Çinarli S, Aykar FS, Sayan A. Attitudes of medical malpractice in pediatric surgery. $J$ Pediatr Res. 2017;4:117-22.

29. Türk Ceza Kanunu, Kanun Numaras1: 5237 Kabul Tarihi:26.09.2004 http://www.mevzuat.gov.tr/MevzuatMetin/1.5.523 7.pdf. 
30. Özdamar K., Paket programlar ile istatistiksel veri analizi (çok değişkenli analizler), Kaan Kitapevi, Eskişehir, (2004)-324-54.

31. Topal E. Sağlık programı stajer öğrencilerinin malprastis bilgi düzeyi ve malpraktis ile ilgili tutumları. 1. Săgllk Mesleki Eğitim Kongresi Bildiri Özetleri Kitabl, 2018;34.

32. Kumar R, Mehta S, Kalra R. Knowledge of staff nurses regarding legal and ethical responsibilities in the field of psychiatric nursing. Nursing and Midwifery Research. 2011;7:1-11.

33. Yöntem S.. Hemşirelerin ilaç hatalarına yönelik bilgi ve tutumları (Yüksek Lisans Tezi). İzmir Kâtip Çelebi Üniversitesi Sağlık Bilimleri Enstitüsü Tibbi Farmakoloji Anabilim Dalı, (2016)İzmir.

34. Yildız T, Eriten G, Erdem İ, et al. Mezuniyetin ve profesyonel sağlık personeli olarak çalıșmanın hasta güvenliği bilinci üzerine etkileri. Kafkas Tip Bilimleri Dergisi. 2012;:94-8.

35. Yildırım İ, Karvan K, Karakaptan E, Ece H. Marmara Üniversitesi hukuk fakültesi ögrencilerinin malpraktis bilgi düzeyleri. MaSCo Ögrenci Kongresi Kitabl. 2011; 17.

36. Babacan E, Öztürk H, Kahriman İ. Tıbbi hatalar ve hasta güvenliği: hemşirelere yönelik eğitimlerin etkinliğinin değerlendirilmesi. Sağllkta Performans ve Kalite Dergisi. 2018;14:57-72.

37. Carter MH. Physicians and medical malpractice: Why do doctors have unwarranted fears? 2015;1204.

38. Odabaşı AB, Tümer AR, Odabaşı O. Bir grup hekimin 5237 sayılı Türk Ceza Kanunu ile ilgili değerlendirmeleri anket çalışması. Adli Tip Bülteni. 2008;13:49-56.

39. Kılıç HS, Elbaş NÖ. Bir eğitim araştırma hastanesinde çalışan hemşire ve doktorların hasta güvenliği hakkındaki bilgileri ve tıbbi hataların bildirilmesi hakkındaki görüşleri. Anadolu Hemşirelik ve Sağllk Bilimleri Dergisi. 2014;17:97-104.

40. Bodur S, Filiz E, Çimen A, Kapçı C. Ebelik ve hemşirelik son sınıf ögrencilerinin hasta güvenliği ve tıbbi hatalar konusundaki tutumu. Genel Tip Derg. 2012;22:37-42. 